\title{
The African American Intellectual of the 1920s: Some Sociological Implications of the Harlem Renaissance
}

\author{
Robert L. Perry \\ and \\ Melvin T. Peters \\ Eastern Michigan University
}

\begin{abstract}
This paper deals with some of the sociological implications of a major cultural high-water point in the African American experience, the New Negro/Harlem Renaissance. The paper concentrates on the cultural transformations brought about through the intellectual activity of political activists, a multi-genre group of artists, cultural brokers, and businesspersons. The driving-wheel thrust of this era was the reclamation and the invigoration of the traditions of the culture with an emphasis on both the African and the American aspects, which significantly impacted American and international culture then and throughout the 20th century. This study examines the pre-1920s background, the forms of Black activism during the Renaissance, the modern content of the writers' work, and the enthusiasm of whites for the African American art forms of the era. This essay utilizes research from a multi-disciplinary body of sources, which includes sociology, cultural history, creative literature and literary criticism, autobiography, biography, and journalism.
\end{abstract}

There were many forces at play from the beginning of the 20th century through the World War, the 1920s, and into the early 1930s that assisted in the emergence of the Harlem Renaissance School of Artists and which encouraged and sustained the growth and vitality of their works, providing wider acceptance for African American cultural subjects than previously possible. Crucial factors in the development of the New Negro era were the vicious racism that ended America's first experiment with living on a democratic basis with African Americans and resulted in the Great Migration (which brought millions of people and their cultural tastes and artistic skills into urban centers of the North), the 
wide variety of black political activists who sought to organize and direct the newly urbanized masses and the cultural renaissance, the modern content of the writing of the era, and the European and Euro-American enthusiasm for Black artistry. Due to America's tragic legacy of monocultural education and cultural hegemony, the actual import of the New Negro Renaissance was officially and prematurely buried. It took the rediscovery of the Harlem Renaissance by scholars, beginning in the 1960 s and working through the 1990s, to clarify the depth of the lasting, universal values that were part and parcel of the movement. Much of this rediscovery indicates just how thoroughly the African American 1920s anticipated the African American 1960s. This paper begins to describe some of the contextual influences upon that seminal moment in African American history and culture.

During the 1920s the phenomenal and controversial activities of a young generation of African-Americans served to capture the imagination of a wide range of the American population. Expressions of this "Harlem Renaissance," "Negro Renaissance," or "New Negro" were cultural in character. Blacks of the era not only created rich modes of literary and musical cultural expression but also struggled to control that expression's image as well as its business affairs. As an intellectual and artistic movement, the Renaissance was firmly rooted in political activism and contained a wide variety of political overtones. Not the least of those who were politically active were the members of the W.E.B Du Bois led National Association for the Advancement of Colored People and the millions of members of Marcus Garvey's United Negro Improvement Association in African and throughout the African Diaspora. Garvey's expansive, black history-rooted activism colored the spirit of the age. His magazine, Negro World, as well as the NAACP's The Crisis focused on all aspects of the political and cultural climate of the 1920s, and both sought to guide the direction of the flourishing cultural production. It was Garvey's unparalleled ability to appeal to and raise funds from the masses of blacks world-wide from his Harlem base that made the UNIA a lightening rod for the actions and reactions of all the other groups interested in black uplift: the integrationists, the socialists, and the communists. Garvey was eventually criminalized and deported by his enemies, both within and outside of the race. ${ }^{1}$ Definitions of the New Negro, his importance as a model of American Culture, and the intent of his activities were argued by black and white alike. Alain Locke, an African American cultural critic, Rhodes Scholar, and a prominent spokesman for the Renaissance described the movement as

...the rise from social disillusionment to race pride, from the sense of social debt to the responsibility of social contribution. Each generation will have its creed and that of the present is the belief in the efficacy of the collective effort in the race co- 
operation. The deep feeling of race is at present the mainspring of Negro life. ${ }^{2}$

He saw hope for the contemporary Black as resting, "in the reevaluation... of the Negro in terms of his own artistic endowments and cultural contribution," although others held opposing views. Replying to poet Langston Hughes and his artistic manifesto, "The Negro Artist and the Racial Mountain," in The Nation, in 1926 black satirist George Schuyler wrote

Negro art "made in America" is as nonexistent as the widely advertised profundity of Calvin Coolidge...or the sophistication of New Yorkers. Negro Art has been, is, and will be among the numerous black nations of Africa; but to suggest the possibility of any such development among the ten million colored people in the republic is self-evident foolishness. ${ }^{3}$

It is altogether curious that the talented and duplicitous Mr. Schulyer, who was a life long opponent of the radical trends of African Americans, by the 1930s would be busy trying his own Black hand as an artist. He published his hilariously signifying, science fiction satire on racial consciousness, Black No More, in 1931 under his own name. As well, he cranked out inventive magazine fiction (Black Empire, The Ethiopian Murder Mystery, and Revolt in Ethiopia) under such pseudonyms as Samuel L. Brooks and Rachel Call. ${ }^{4}$

Despite the 1920s debate over whether the Renaissance was a declaration of cultural autonomy or an exercise in self-delusion, it held the attention of the American public then and influenced future forms of Black artistry on an international scale. In that era Langston Hughes, Zora Neale Hurston, Claude McKay, Wallace Thurman, Countee Cullen, Jessie Fauset, Jean Tommer, Rudolph Fisher, and James Weldon Johnson established reputations as popular poets, short-story writers and novelists. Sociologist E. Franklin Frazier along with historians J.A. Rogers, Carter G. Woodson, and Alain Locke gained a wide readership in scholarly and popular circles. Louis Armstrong, Alberta Hunter, Paul Robeson, Roland Hayes, Duke Ellington, James Reese Europe, Josephine Baker, Gertude "Ma" Rainey and Bessie Smith were but a few of the acclaimed actors, musicians and dancers who became public figures, both here and abroad. Black America experienced in the 1920s a sudden recognition and, in some cases, a sincere appreciation of a few of its talented members. The audiences that received these intellectuals and artists fed additional enthusiasm into the movement, promoting and encouraging the emergence of other talent, such as A. Philip Randolph and Cyril Briggs in journalism, Angelina Grimke and George Douglas Johnson in drama and Aaron Douglas in art. The prophetic 
ideals of the young radicals among the era's creative spirits were vindicated by the work of future artists. Hughes' 1926 declaration, "We younger artists that create now intend to express our individual darkskinned selves without fear or shame...We build our temples for tomorrow, strong as we know how, and we stand on top of the mountain, free within ourselves," ${ }^{5}$ has proven to be extremely influential throughout the twentieth century. Janheinz Jahn, among others, has noted that the Harlem Renaissance had a direct influence on the Negritude Movement of French speaking Caribbean and African writers. ${ }^{6}$ Similarly, writers of America's Black Arts Movement of the 1960s and early 1970s represented their work as "the New Black Renaissance." A final indication of the enduring impact of the New Negro Movement comes from the literary poets of the Hip-Hop generation. The editors of In the Tradition: An Anthology of Young Black Writers (1992) assert that, "we are echoes of the Harlem Renaissance- Zora Neale, Langston, Countee, Nella, Claude, et al." ${ }^{\prime}$

\section{The Pre-1920s Background}

"New Negroes" of the Renaissance were emerging from an America that had experienced vast changes in the late 19th and early 20th centuries. Industrialization, urbanization, and the rise of the middle class marked the end of the Civil War, with Reconstruction redefining social order and mood. Within this period of change, it was African-Americans who were most greatly affected. From 1890 to 1920 more than two million Negroes left Southern farms for the city and factory. ${ }^{9}$ Just two decades later, the proportion of African-Americans residing in urban areas in America had "increased from $28 \%$ to $48.2 \%$." 10 Alain Locke described this movement as "a deliberate flight not only from the countryside to city, but from medieval America to modern." ${ }^{11}$ Black men and women shifted from an agrarian world to an industrial one, from constituting a peasantry to joining an urban proletariat. One result of the massive migration was the creation of Black Harlem, the center of the Renaissance. Illogical land and building speculation and the resulting frantic "collapse of the real estate values, suddenly transformed an area for the well-to-do into a fashionable slum for New York's Negroes." ${ }^{12}$ From 1900 to 1920 the population of Harlem increases rapidly and "it gradually acquired the character of a 'race' capital. Negroes from Africa and the West Indies, from the North and the South...poured into the crucible of the dark Manhattan. Harlem thus provided the Negro artist with an infinite number and variety of human subjects." 13 The crowded city fostered vigorous group life, and the African-Americans began to see their problems collectively. The urban environment put an end to isolated provincial attitudes; traditional ways of thinking, formed as survival strategies during the severe test of slavery, were modified. A general lack of 
work gave many of "the Harlem Negroes the opportunity for individual contacts with life and the spirit of New York."14

The migration of million of culture-bearing African Americans into the cities included laborers, middle class professionals, and artists alike. Even as the racist "Separate but Equal" was being put into place, the racially distinctive musical gifts of the culture captured the attention of white Americans and set them to dancing. It is of major significance to note that the integral part music plays in most aspects of African American life is a definite retention from African culture which has continually served to produce outstanding artists. The importance of the idea of Africa is reflected in stylistic techniques (much of which remained subliminal) but also in the naming of songs both before and after Marcus Garvey. There were among the early 20th century ragtime tunes such titles as" "African Dreamland," "An African Reverie," "Under the Bamboo Tree," and Eubie Blake's "Sounds of Africa." Early jazz songs featured titles like "Pharaoh Land," "Senegalese Stompe," "South African Blues," "African Hunch," "Shakin' The African," and The Mills Brother's "Jungle Fever." 15 The popular arrival of ragtime music around 1900 set the stage for the introduction of the other musical genres; jazz and blues were already incubating in all Black settings in the Deep South and were trickling into the North. "The Jazz Age actually started in 1912 when musicians first referred to 'jazzing' music but was recognized by the world around 1918 or 1920 ."16 The culturally focused activism of a multitalented group of African Americans, generally one generation out of slavery, led the struggle to put their music on America's center stage.

The far-sighted among the oppressed saw in their music a powerful tool to be used in the fight against both segregation and the racist attitudes.... The picket lines and lawsuits broadened opportunities for Black artists in the North, while at the same time there were musical forays into the Southern backwaters by jazz and blues groups who proved to be so popular that they generated integrated audiences despite segregation laws. Then there were the musicians turned radicals. And at the same time community activists aided the music cause, as for example when the NAACP underwrote the first major Black-owned record company. ${ }^{17}$

Key figures at this developmental stage of the New Negro Renaissance included the following cultural pioneers: Lester A. Walton, desegregation activist, theater manager, and theater-page journalist; W.C. Handy: musician, composer, sheet-music businessman, and author; Sherman Dudley: theater booking-agency owner; Jack Johnson: heavyweight champion of the world and jump-starter of Chicago's cabaret business with his integrated clubs; and James Reese Europe: organizer of The Clef Club in New York that started the process of obtaining unionized status for Black musicians and bandleader of the U.S. Army 369th Infantry Band in France that, pivotally, introduced jazz to the world 
during World War I. Europe, whose Clef Club dates back to 1910, also pioneered the arena of interracial cultural collaboration around Black art forms through work as musical director for the influential dance team of Vernon and Irene Castle. ${ }^{18}$ The segregated African American educational institutions of the South were well-organized training schools for many of the future "names" of the Jazz Age and beyond. ${ }^{19}$

The groundwork had been so thoroughly laid that, as Ted Vincent observes in his pioneering socio-cultural study, Keep Cool: The Black Activists Who Built the Jazz Age (1992), ${ }^{20}$ when "the profiteers...proclaimed the 'discovery' of a new world of music...[they] found a Black civilization that had already provided its musicians with the necessary guidance and institutional support."21 Much of the struggle of the Roaring 1920s involved the destruction of this hard-won African American cultural infrastructure. As W.C. Handy points out about the demise of a once thriving music publishing firm, "The beast of racial prejudice was rearing its head...Add to such difficulties the bitterness of sharp competition, and you have the materials for a minor tragedy". ${ }^{22}$

Both racial prejudice and previous African American political movements helped to support and define concepts of racial identification and pride that became central to the unfolding of the nature of the Renaissance. The NAACP was an outgrowth of the Niagara movement in which W.E.B. Du Bois was a prominent factor. With his guidance, the organization quickly established a reputation as an upcoming force in the fight to secure full participation in American life for its people. In the pre-Renaissance era, Du Bois used his editorship of the organization's magazine, The Crisis, as a forum in which to examine such issues as the anti-lynching campaign and the participation of African Americans in World War I. On the one hand, he recognized that enlistment could serve as a means of stimulating upward mobility for the race; on the other hand, he remained suspicious about what real effect that participation would mean in the context of the historically poor treatment of Blacks in the United States. His reluctance to fully endorse such enlistment proved to be eminently justified. Pride of accomplishment and the realization of strength on the part of Blacks in the military too quickly turned into disillusionment when the troops were pointlessly segregated and continually maligned, even becoming targets in more than a few race riots.

The highly significant and best received novel of the pre-Renaissance era of African American literature was James Weldon Johnson's anonymously issued The Autobiography of an Ex-Coloured Man (1912). ${ }^{23}$ This book foreshadowed many of the thematic concerns of Renaissance fiction in its depiction of the music driven-urban nightlife social strata. Johnson, himself an internationally popular composer and entertainer, drew upon personal experiences in his portrayal of African American club owners, the emergence of ragtime music, and the in- 
tense interest of white artists and fans in the developing milieu. Paul Laurence Dunbar's Sport of the God (1902) somberly depicts the disintegration of a decent Southern family in a Babylon-like urban setting. The militant fiction featuring racism and segregation fighting revolutionary themes and characters as in Du Bois' Dark Princess (1928) were presaged to a degree by Sutton E. Griggs' Imperium in Imperio (1899) focused on nationalist and separatist ideology.

\section{The Forms of Black Activism in the Renaissance}

During the 1920s a wide variety of socio-political groups joined in the racial uplift fray and ultimately competed with the NAACP over the question of the leadership of the African American masses. Garvey's UNIA, which had historical roots in the Africa focused nationalism of Martin Delany, Edward Blyden, and Bishop Henry McNeal Turner, among others, ${ }^{24}$ was the most successful mass movement of Blacks in modern history. "The UNIA...by the mid-1920s boasted over eleven hundred branches in over forty countries in North, South, and Central America, the Caribbean, Africa, Europe, and Australia."25 Also on the scene were Cyril Brigg's communist supported African Blood Brotherhood and their magazine, The Crusader, and A. Phillip Randolph's socialist monthly, The Messenger. Garvey, Randolph, Briggs, and Du Bois were spied upon by J. Edgar Hoover and the FBI. ${ }^{26}$ Extraordinary by today's standards was the presence of the Caribbean born Casper Holstein, the developer of Harlem's lucrative numbers racket, which Dutch Schultz eventually invaded. Holstein, a race conscious man of culture, "annually contributed a substantial literary prize" and was fictionalized in Carl Van Vechten's 1926 book, Nigger Heaven. ${ }^{27}$ Especially close to Garvey, Holstein has been regarded by some scholars, "as one of six individuals without whom the cultural 'Harlem Renaissance' would not have been possible." 28

All of the groups provided extensive coverage and support of the cultural creations of the Renaissance. This was especially true of the literature, although both Du Bois and Garvey openly quarreled with writers they considered to be wayward, notably Claude McKay. Many of the writers were published in both The Crisis and Negro World. ${ }^{29}$ Garvey's organization was intimately involved with the music. The UNIA had some forty bands regularly performing at its functions and generated several songs like the 1924 hit "West Indies Blues" and "Black Star Line," which lauded Garvey in the manner of contemporary reggae music. Garvey himself composed the lyrics to "Keep Cool" that was advertised in 1927 as "the sheet-music 'Song Hit of the Season'." ${ }^{30}$ Both Briggs and Randolph were ardent supporters of music. Briggs went so far as to establish the short-lived firm, The Crusader Music Company, for the publication of radical song lyrics like those of Andy Razaf, Thomas "Fats" 
Ethnic Studies Review Vol. 19, No. $2 \& 3$

Waller's lyricist, the author of "(What Did I Do To Be So) Black and Blue" and one-time editor of The Crusader magazine. ${ }^{31}$

The NAACP's attitude toward the music was decidedly more complex and ultimately tragic. Although the organization underwrote Harry A. Pace's Black Swan records in 1921, amply demonstrating there was a lucrative market for African American jazz and blues, Pace's recording of blues artists like Mamie smith, Alberta Hunter, and Trixie Smith became a source of embarrassment to the classical musical tastes of the NAACP hierarchy. Pace once, infamously, refused to record the legendary Bessie Smith. The Crisis advertised Black Swan's products, yet regularly ignored reporting on the popularity of jazz and blues and its creators. Faced with internal conflict and pressure from music industry giants as well as unknown others (the company received a shrapnel bomb in a coal shipment in 1922) from without, the company was soon on shaky ground. Before its 1923 demise, Black Swan was emphasizing classical recordings feeling that such works reflected more favorably on the race. ${ }^{32}$

\section{The Modern Content of the Writer's Work}

The Puritanism, materialism, and racism that characterized America in the first decades of the twentieth century was rejected by especially the youth among the Renaissance intelligentsia. The younger writers of the 1920s were the educated--"the wayward sons of the rising middle class." ${ }^{33}$ Their lives displayed similar rebellious patterns. Langston Hughes, "at the insistence of his businessman father spent a year studying at Columbia University, after which in disgust he shipped out on a freighter to Africa." ${ }^{34}$ Hughes would write later, "My father was what the Mexicans call muy Americano; a typical American.... He was interested only in making money." ${ }^{35}$ Actor Paul Robeson was raised by his runaway slave father, a tough-minded preacher, who demanded perfection from his son. Robeson aspired to his father's values, becoming the third Black to attend Rutgers, getting elected to both the Phi Beta Kappa honorary society and All-American Football Team, and finally graduating from Columbia Law School. He practiced law only briefly, however, then won the lead in Emperor Jones with the Provincetown Players. After he quit the law firm, Robeson relaxed and changed. He never bothered to look for another job, and "boast[ed] that he [was] as good a loafer as any man living." ${ }^{36}$

Jean Toomer also pursued literature though his endeavors were not supported by his family, in particular his grandfather, the high-ranking Reconstruction politician from Louisiana, P.B.S. Pinchback. Countee Cullen, son of a noted Harlem minister and one-time husband of W.E.B. Du Bois' daughter, rebelled against formal religion in his novel One Way to Heaven. Rebellion from bourgeois values, however, was far from the 
norm among artists and the intellectuals of the era. A dichotomy of values existed among those associated with the Renaissance. Writers such as Jessie Fauset, Walter White, and Nella Larsen, often identified as the "Rear Guard," projected middle class values in their work. Such conservative writers were often perceived as propagandists trying to placate whites' opinions. Comparing work of the Rear Guard's Larsen to Claude McKay of the Harlem School reveals the posture of both groups. "Bita" in McKay's Banana Bottom and Larsen's "Helga Crane" in Quicksand were both raised and prepared to participate in a white-dominated culture. Through varying circumstance, however, both characters return to the folk. "That one author (Larsen) interprets this event as a tragedy and the other as a natural expression of cultural dualism is a measure of their respective attitudes towards bourgeois society." ${ }^{37}$

In contrast to the emphasis on assimilation promoted by writers of the Rear Guard was the philosophy of cultural dualism or pluralism characteristic of the Harlem School. Their nationalism was not based on racial considerations alone; it was motivated by factors related to the universal revolt of the modern artist from bourgeois civilization. The Negro intellectual of the 1920s shared fully in the spiritual alienation as an artist which causing him to alter his goals as a Negro. Instead of advocating blind assimilation into a hopeless, materialistic, culture, he began to think in terms of preserving his racial identity.

The character of dualism was a "forced attempt to build [the Negro's] Americanism on racial values" and was "a unique social experiment, its ultimate success...impossible except through the fullest sharing of American culture and institutions." 38

The focus of the Harlem School served, to an extent, to define the subject matter emphasized by the school's writers who chose themes that were distinctively African American. The middle class and middle class materialism were rejected as being white-identified. The lower classes and "folk" of slave origins were embraced as central figures of the new literature: "there are the low-down folk... and they are the majority - may the lord be praised!... They furnish a wealth of colorful distinctive material for any artist because they still hold their own individuality in the face of the American standardization." ${ }^{39}$ The work of Langston Hughes and Claude McKay, in particular, often took a Pan-African focus. The folk resisted cultural assimilation, as is indicated in a description of a character in Claude McKay's novel, Banjo, which deeply involves the adventures of a Pan-African jazz band in France:

This primitive child, lies kinky-headed big laughing big boy of the world, did not go down and disappear under the serried crush of trampling feet; that he managed to remain on the scene...not machine-made nor poor-in-spirit like the regimented creatures of civilization, was baffling to civilized understand- 
ing.... He was a challenge to civilization itself. ${ }^{40}$

Looking at the Renaissance from a half-century away, critic Charles T. Davis enhances McKay's ideas about the folk and the importance of folk wisdom and about their long-term effects on American society and on African-American cultures. He writes that

what saved the Renaissance was [that] the artists...intelligent, more sensitive, and more compassionate, had made the right guess.... [Today] increasing discontent with the machine age and a mounting dismay at the consequences of nuclear fission...the menace of nuclear war have led to an affirmation of the values of community and a renewed affection for the planet earth. The folk tradition...prospers, affording models for life and for art. This exploration, now an industry constantly expanding, confirms the right of folk knowledge to stand beside formal history, science, and art as one of the pillars of civilization. The cantankerous grandmother of [Ishmael] Reed's The Free-Lance Pallbearers may yet receive a Ph.D. in Hoodoo, supported by government funding resembling the benefits of the G.I. bill. ${ }^{41}$

To possess a distinctive culture, a distinctive language must be used. Terms like "ofay" (white man, from pig Latin for "foe") and "redbone" (a high-toned Black) were used so frequently in the works of the Harlem School that some individual authors writing for mixed audiences, notably Rudolph Fisher in The Walls of Jericho ${ }^{42}$ and Zora Neale Hurston in "A Story in Harlem Slang," ${ }^{43}$ created glossaries to explain contemporary African American phraseology. All of Langston Hughes' writing was similarly important in the recognition of Black talk as was McKay's fiction. Both of them brought jazz-influenced writing techniques into American literature. And Hughes almost single handedly made the blues form a part of the poets' arsenal.

Frequent motifs contained in the writing produced by the Harlem School dealt with depicting and attacking the sacred cows of sexuality, color caste, and, less frequently, gender relations. In Banana Bottom, Claude McKay used sex as a vehicle to dramatize one character's conflict between the Calvinistic austerity of the white missionaries who raised her and the primitive sexuality and simple values of the "Obeah God" folk. In Cane Jean Toomer examines sensuality and sexism in portraits of six southern women and the gender exploitation that causes one of them to become a prostitute. ${ }^{44}$ The sexuality of young Harlem cabaret dancers was detailed in many works. Some of the works constituted milestones in America literature; the play Lulu Belle "was indeed something of a turning point.... play that could be staged that involved sex between white and black, love-making [that had] been going on for three 
hundred years." 45 The multi-talented Hurston (fiction writer, dramatist, essayist, and anthropologist) foretold the future of women's literature with her ability to write with rare dramatic clarity and satire on the many forms of male sexism. Her landmark short story on spousal abuse, "Sweat" (1926), ${ }^{46}$ especially, and her novel length study of marriage and African American male chauvinism, Their Eyes Were Watching God $(1937)^{47}$, rank her as America's first literary feminist. In this she seems to have taken her cue from the many African American female blues singers that emerged in the wake of Gertude "Ma" Rainey in the 1920s, especially Bessie Smith. A number of Smith's songs certainly represent, "bold efforts to dignify women." 48 Hurston had a large interest in earthy music created by Blacks in the Americas. She collected, recorded, and wrote about it anthropologically in Mules and Men (1935) and Tell My Horse (1938). Hurston "was a writer of blues songs as well. [Porter] Grainger recorded a Hurston blues titled 'Jelly Look What You've Gone Done'."49 Grainger was frequently Bessie Smith's piano player in the 1920s.

\section{White Enthusiasm for Black Art Forms}

A number of white artists associated themselves with the culture, subject matter and the people of the Harlem Renaissance. Eugene O'Neill was an important pioneer in this vein. His first four plays: The Moon of the Caribees, The Dreamy Kid (a play about a Harlem gangster), The Emperor Jones, and All God's Children Got Wings, dealt with increasingly complex characterizations of African Americans. ${ }^{50}$ This trend was followed by Sherwood Anderson's Dark Laughterand Du Bois Heyward's Porgy, among many other lesser lights. These writers helped create an audience amenable to serious literary treatments of Black subjects. The introduction of African America into mainstream American literature allowed the race's writers access to previously segregated associations and institutions. Personal association with white authors meant an inevitable end to cultural isolation and provincialism and an immense gain in technical maturity for the Black writer. Carl Van Vechten was of major importance as a facilitator of this inter-racial interaction.

Cultural collaboration between the races was not always successful, however. Du Bois identified Eugene O'Neill as being one of the few white artists to have succeeded at sensitively portraying Blacks in his plays. But Charles Gilpin, one of the first successful actors of his race in serious drama argued with O'Neill when playing the role of Brutus Jones in The Emperor Jones. He resigned his role in the play because of his insistence that particular language he objected to be changed.

None of the white writers of the period stirred as much controversy as did Carl Van Vechten, author of Nigger Heaven. Van Vechten's role in alerting his white colleagues to the New Negro Movement proved 
helpful, but how helpful the novel was to the movement remains debatable. "Emphasizing the bawdy and exotic aspects of Harlem life and heavily influenced by primitivistic conceptions, Nigger Heaven shattered the complacence of the Negro intelligentsia by threatening to steal their literary thunder." 51

The presence of white artists in the Renaissance created a certain suspicion that many Black artists' motive for creating was, in fact, merely to entertain rather than to educate white audiences. The suspicion may have been justified: some of the culturally distinctive characteristics which Renaissance writers utilized to emphasize race pride were the same exaggerated aspects in caricatures of Blacks by ignorant and bigoted whites.

Responding to this dilemma in The Crisis, Van Vechten compared his work to that of Rudolph Fisher, an African American writer and doctor of medicine whose stories contained controversial urban themes: "If a white man had written [Fisher's Stories] he would be called a Negro Hater. Now these stories would be just as good if a white man had written them, but the sensitive Negro--and heaven knows he has reason enough to be sensitive--would see propaganda therein." ${ }^{2}$ Langston Hughes and Countee Cullen replied that any artist must have the right to use any subject material in any way he wishes, according to his own conscience. African-American writers felt that an honest and intelligent audience could distinguish between bigotry and artistic realism.

White participation in the New Negro Movement fostered an image of African Americans that reflected and supported white intellectuals' longing for abandon. The years of the Renaissance were

years of postwar catharsis of Freud and the sexual revolution, of heavy drinking and defiance of authority...interest in the Negro focused around the cult of the primitive... reflecting the works of Sigmund Freud, it exalt[ed] instinct over intellect, Id over Super Ego, and thus [was] a revolt against the Puritan spirit. For such an artistic movement the Negro had obvious uses: he represented the unspoiled child of nature, the noble savage-carefree, spontaneous and sexually uninhibited..$^{53}$

White audiences' interest in the Renaissance appears to have been so intense it constituted a kind of voyeuristic cult. However, the prevailing image of African American artistic accomplishment was a carefully managed affair by the white establishment. ${ }^{54}$ The image of Harlem held by whites was a primitive and exotic one, produced by the popular "slumming" parties and cabarets operated by whites for whites which were, for many, their primary contact with Harlem.

What was tragic and oppressing about Harlem and the general condition of African America was ignored. ${ }^{55}$ Langston Hughes main- 
tained that despite the optimism of the bourgeois, ultimately, the cultural movement made no discernible impact on the lives of the residents of Harlem. As he put it in the first volume of his autobiography,

Some Harlemites thought that the millennium had come.... I don't know what made any Negroes think that - except that they were mostly intellectuals doing the thinking. The ordinary Negroes hadn't heard of the Negro Renaissance. And if they had, it hadn't raised their wages any. ${ }^{56}$

Generally speaking serious art depicting Harlem, or Blacks anywhere, did not enjoy commercial success. Among the Black writers of the era, only Claude McKay's controversial Home to Harlem attained a large number of sales. McKay compared the reception of this book to being, "like an impudent dog...[moving] right in among the best sellers in New York." ${ }^{57}$ The sensational Nigger Heaven by Van Vechten ran quickly through several editions, whereas Jean Toomer's Cane sold hardly five hundred copies in its fifth year. Du Bois reviewed Nigger Heaven making important distinctions about the characters and intentions of whites involved in the Renaissance. Du Bois observed about Van Vechten that "to him the black cabaret is Harlem; around it all his characters gravitate." These cabarets, financed, supported and owned by white New York did not reveal realistic characteristics of Harlem. Both Langston Hughes and Carl Van Vechten knew Harlem cabarets, but it was Hughes who whispered, "One said he heard the jazz band sob when the little dawn was grey. Van Vechten never heard a sob in a cabaret. All he [heard was] noise and brawling." 58

Different interpretations and values caused criticism of the Renaissance to be sometimes confused and contradictory. Du Bois and The Crisis opposed cultural assimilation of the Black, fearing Black Art could be destroyed by "the overemphasis of Ethnics...meet[ing] the Puritans....who conceal their joys and deny them with crass utilitarianism." ${ }^{59}$ Yet in a later review Du Bois wrote that Claude McKay's Home to Harlem, while it showed evidence of McKay's characteristic cultural content and political intent, "for the most part nauseates me, and after the dirtiest of its filth I feel distinctly like taking a bath. ${ }^{n 60}$ Culturally and politically a militant African American nationalist, Du Bois was already in his mid-fifties when the Renaissance began and his attachment to Victorian values, especially class and sexual values, inhibited to a great degree his ability to assess works of the Harlem School.

Some Renaissance critics suggested the concept of Negro Art promoted a paternalistic segregation. When singer Roland Hayes performed German and French pieces his audiences were surprised and he received moderate applause. The consensus was that Hayes was best with spirituals, or "songs of this race." Some Blacks objected to the 
racial concepts of "Negro Art" and the limitations that those concepts imposed: "Even with her eyes closed America must always be able to tell...Negroes were darkies. Perhaps that is why...Roland Hayes is returning to France to live." 61 The assumption that such limitations caused Hayes to retreat to France is not convincing. Protesting not treatment received individually but the values and ethics of America in general, many artists, Black and white, went into voluntary exile in that same time period. Paul Robeson lived in Europe from 1928 until 1939 not because of direct discrimination (by his own account he experienced little) but "as a rebellion against American attitude on race."62

Establishment of African American Art in America was considered impossible by one New Negro critic who enjoyed warm response during the Renaissance era because he opined "the Afro-American is merely a lampblacked Anglo-Saxon expressing an unconscious urge toward whiteness." ${ }^{63}$ Langston Hughes discounted such negative thinking and sharply criticized members of the middle class for having a "desire to run away spiritually from [the] race...[an] urge...toward whiteness, [a] desire to pour racial individuality into the mold of American standardization, and to be as little Negro and as much America as possible."64

However varied reaction to the Harlem School was, its artists and intellectuals understood their world was going through many remarkable and rapid changes. Likewise, the so-called Rear Guard perceived the times with their own genteel views. Nevertheless, whether they turned to the folk for wisdom or whether they plied the turbulent waters of accommodation, Renaissance artists, writers, intellectuals and leaders produced a body of work which served to free African-American to embrace subject matter which they themselves best understood. The New Negro of the Harlem Renaissance helped establish African Americans intellectually, artistically, and socially in American Culture, changing forever the way white Americans could look at African Americans. Langston Hughes said it early into the unfolding of the Renaissance: "It [was] the way people look[ed] at things, not what they look[ed] at, that...changed." ${ }^{65}$ The rest of the 20th century has revealed an essential part that changed the way of seeing what has been the solidification of the place of the once feared and scorned art forms of the Harlem Renaissance era in American and world culture. The respected and much imitated place of these art forms is made evident by publication of edited texts that bring the literature and the music into the same field of vision: Art Lange and Nathaniel Mackey's Moment's Notice: Jazz in Poetry \& Prose (1993); Sascha Feinstein and Yusef Komunyakaa's The Jazz Poetry Anthology (1991) and The Second Set: The Jazz Poetry Anthology, Vol. II (1996); Eric Sackheim's The Blues Line: An Anthology of Blues Lyrics (1975); and X. A. Nicholas' Woke Up This Mornin': The Poetry of the Blues (1973). The struggle for African American control of their indigenous culture expression, however, continues. 


\section{NOTES}

'Ward Churchill and Jim Vander Wall, The Cointelpro Papers: Documents From the FBl's Secret War on Dissent in the United States (Boston: South End Press, 1990), 11.

${ }^{2}$ Alain Locke ed., The New Negro: An Interpretation (New York: Albert \& Charles Boni, 1925), 11.

${ }^{3}$ George S. Schuyler, "Negro-Art Hokm," Voices of the Harlem Renaissance, Nathan Huggins ed., (New York: Oxford University Press, 1976), 309.

${ }^{4}$ RobertA. Hill, Ethiopian Stories (Boston: Northeastern University Press, 1994), 41.

5Langston Hughes, "The Negro Artist and the Racial Mountain," Voices of the Harlem Renaissance, Nathan Huggins ed., (New York: Oxford University Press, 1976), 305-9.

${ }^{6}$ Janjeinz Jahn, Neo-African Literature: A History of Black Writing (New York: Grove Press, 1968), 214, 228, 244.

'Don L. Lee, Directionscore: Selected and New Poems (Detroit: Broadside Press, 1971), 24.

${ }^{8}$ Kevin Powell and Ras Baraka, In the Tradition: An Anthology of Young Black Writers (New York: Writers \& Readers Publishing, 1992), 14.

${ }^{9}$ Robert A. Bone, The Negro Novel in America (New Haven: Yale University Press, 1958), 53-4.

${ }^{10} \mathrm{Abdul}$ Alkalimat, Introduction to Afro-American Studies (Chicago: 21st Century Books and Publications, 1986), 101.

"Locke, 6.

${ }^{12}$ Robert H. Wiebe, The Search for Order 1877-1920 (New Haven: Yale University Press, 1958), 53-4.

${ }^{13}$ Bone, 54. 
14James Welden Johnson, "Harlem: The Cultural Capital," The New Negro (New York: Albert and Charles Boni, 1925), 301-11.

${ }^{15}$ Norman C. Weinstein, A Night in Tunisia: Imaginings of Africa in Jazz (New York: Limelight Editions, 1993), 29.

${ }^{16}$ Ted Vincent, Keep Cool: The Black Activists Who Built the Jazz Age (London: Pluto Press, 1995), 2.

${ }^{17}$ Vincent, 1-2.

${ }^{18}$ Tim Gracyk, "Liner Notes", James Reese Europe's 369th U.S. Infantry's A Hellfighters Band: The Complete Recordings (Memphis: Memphis Archives, 1996), 3-33.

19John F. Szwed, Space is the Place: The Lives and Times of Sun Ra (New York: Pantheon, 1997), 16-32.

${ }^{20}$ Vincent, 1.

${ }^{21}$ Vincent, 1.

${ }^{22}$ W. C. Handy, Father of the Blues: An Autobiography (New York: Da Capo Press, 1941, 1991), 199-202.

23Johnson, 301-11

${ }^{24}$ Wilson Jeremiah Moses ed., Classical Black Nationalism: From the America Revolution to Marcus Garvey (New York: New York University Press, 1996), 27-9.

${ }^{25}$ Tony Martin ed., Literary Garveyism: Garvey, Black Arts \& The Harlem Renaissance (Dover: The Majority Press, 1983), 2.

${ }^{26}$ Churchill and Vander Wall, 350.

${ }^{27}$ Rufus Schatzberg and Robert J. Kelly, African American Organized Crime: A Social History (New Brunswick: Rutgers University Press, 1997), 67-8.

${ }^{28}$ Vincent, 181.

${ }^{29}$ Martin ed., African Fundamentalism: A Literary and Cultural Anthology of Garvey's Harlem Renaissance (Dover: The Majority Press, 1991), xvi-xvii.

${ }^{30}$ Vincent, 125, 131, 136. 
${ }^{31}$ Vincent, 13.

${ }^{32}$ Du Bois, W. E. B. The Crisis, Vol. 28-29, (June 1924): 103-5.

${ }^{33}$ Bone, 56.

${ }^{34}$ Edwin R. Embree, Thirteen Against the Odds (New York: The Viking Press, 1944), 126.

${ }^{35}$ Bone, 56.

${ }^{36}$ Embree, 245-9.

37Bone, 24.

${ }^{38}$ Locke, 12.

${ }^{39} \mathrm{Hughes,}$ The Big Sea: An Autobiography (New York: Knopf, 1940), 306.

${ }^{40}$ Claude McKay, Banjo: A Story Without A Plot (New York: Harcourt Bruce Jovanovich, 1929 (1957)), 314.

${ }^{41}$ Charles T. Davis, Blacks is the Color of the Cosmos (Washington, D. C.: Howard University Press, 1989), 74-5.

${ }^{42}$ Rudolph Fisher, The Walls of Jericho (New York: Arno Press, 1928, 1969), 295-307.

${ }^{43}$ Zora Neale Hurston, The Complete Stories (New York: Harper Collins, 1995), 134-8.

${ }^{44}$ Bone, $72,82$.

${ }^{45}$ Du Bois. The Crisis, Vol. 32, (October 1926): 34.

${ }^{46}$ Hurston.

${ }^{47}$ Hurston. Their Eyes Were Watching God (New York: Harper Collins, 1937).

${ }^{48}$ Vincent, 147, 231.

${ }^{49}$ Vincent, 147, 231. 
${ }^{50}$ Sterling A. Brown, Negro Poetry and Drama \& The Negro in American Fiction (New York: Athneneum, 1937, 1969), 124-5.

${ }^{51}$ Bone, 61.

${ }^{52}$ Carl Van Vechten, "The Negro in Art, How Shall He Be Portrayed-A Symposium," The Crisis, Vol. 31, (March 1926): 219.

${ }^{53}$ Bone, 59.

${ }^{54}$ Barry Singer, Black and Blue: The Life and Lyrics of Andy Razaf (New York: Schirmer Books, 1992), 216-20.

${ }^{55}$ Gilbert Osofsky, "Symbols of the Jazz Age: The New Negro and Harlem Discovered", American Quarterly, Vol. 17, No. 2, (Summer 1965): 234-6.

${ }^{56}$ Hughes, 228.

${ }^{57}$ Wayne Cooper, Claude McKay: Rebel Sojourner in the Harlem Renaissance (New York: Schocken Books, 1987), 237.

${ }^{58}$ Du Bois. "Books," The Crisis, Vol. 24, (December 1926): 31.

${ }^{59}$ Du Bois. The Crisis, Vol. 24-25, (November 1922): 7.

${ }^{60}$ Du Bois. "Two Novels," The Crisis, Vol. 24-25, (June 1928): 202.

${ }^{61 G u s t a v o u s ~ S t e w a r d, ~ " S e g r e g a t i o n ~ d e ~ L u x e, " ~ T h e ~ N a t i o n, ~ V o l . ~ 131, ~ N o . ~}$ 3402, (17 September, 1930): 295-6.

${ }^{62}$ Embree, 126.

${ }^{63}$ Schuyler, 310.

${ }^{64}$ Hughes, 305.

${ }^{65}$ Hughes. "The Negro in Art, How Shall He Be Portrayed-A Symposium," The Crisis, Vol. 31, (April 1926): 278. 